\title{
大腿骨顆上骨折の治療経験
}

\author{
国立熊本病院整形外科 \\ 寺 本 弘・野 村 一 俊 \\ 平 野 真子・橋 本 伸 朗 \\ 福元哲也
}

\section{Clinical Experience of Supracondylar Fractures of the Femur}

by

Hiroshi Teramoto, Kazutoshi Nomura, Mako Hirano, Noburo Hashimoto and Tetsuya Fukumoto

Department of Orthopaedic Surgery, Kumamoto National Hospital, Kumamoto, Japan

Internal fixation of femoral supracondylar fractures is sometimes difficult, especially when it is performed in elderly patients with osteoporosis. In those cases it is often difficult to begin ROM exercise and weight-bearing immediately after surgery.

Ten cases of supracondylar fracture of the femur which were operated on at our hospital during 1991-1995 were reviewed. Nine patients were female, one was male with an average age of 78.5 years. The mean follow-up period was 22.8 months. Clinical results were evaluated using Neer's criteria: Excellent $=4$; Satisfactory $=3$; Failure $=3$.

Factors which were associated with unsatisfactory results were severe osteoporotic conditions, general complications and osteoarthritis of the knee joint. It is necessary to establish a safer material and method to begin ROM exercise and weight-bearing in the early post-operative period.

Key words : Supracondylar fracture of the femur (大腿骨顆上骨折), Post-operative evaluation (術後評価), Intramedullary supracondylar nail

\section{はじめに}

大腿骨顆上骨折は；骨粗鿏症を基盤に持つ高龄者に

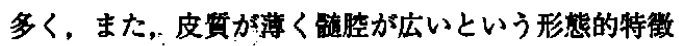
により，しばしば，強固な内固定の施行が困䨼となる。 そのため，早期の可動域訓練や，荷重負荷が出来ない ことも多く，治療法が確立されているとは言い難い。 今回我々は，過去 5 年間に当院で手術を施行した症例 の, 術後成灣等を調查し，その問題点を検討したので 報告する。

\section{対象および方法}

対象は，平成 3 年 1 月から，平成 7 年 12 月までに, 当院にて手術を施行した 13 例のうち, 肺踇, 再生不
舞 1 骨折型と固定材

\begin{tabular}{c|c|c}
\hline \hline 症例 & 学折型 & 固定材 \\
\hline 1 & III & May-plate \\
2 & II & rush-pin \\
3 & III & rush-pin \\
4 & II & DCS \\
5 & V A & IMSC \\
6 & V A & IMSC \\
7 & II & IMSC \\
8 & N A & IMSC \\
9 & III & IMSC \\
10 & N A & IMSC \\
\hline
\end{tabular}


表 2 術後成績

\begin{tabular}{c|c|c|c|c|c|c|c}
\hline \hline 症例 & Pain & Function & Motion & Work & Anatomy & Total & 評伴 \\
\hline 1 & 20 & 8 & 16 & 10 & 21 & 75 & Satisfactory \\
2 & 16 & 8 & 16 & 10 & 15 & 77 & Satisfactory \\
3 & 8 & 20 & 0 & 10 & 15 & 53 & Failure \\
4 & 20 & 8 & 16 & 2 & 24 & 70 & Satisfactory \\
5 & 20 & 0 & 0 & 10 & 15 & 45 & Failure \\
6 & 20 & 20 & 12 & 10 & 30 & 92 & Excellent \\
7 & 20 & 0 & 0 & 10 & 24 & 54 & Failure \\
8 & 20 & 12 & 16 & 10 & 30 & 88 & Excellent \\
9 & 20 & 20 & 12 & 10 & 24 & 86 & Excellent \\
10 & 20 & 16 & 20 & 10 & 24 & 90 & Excellent \\
\hline
\end{tabular}

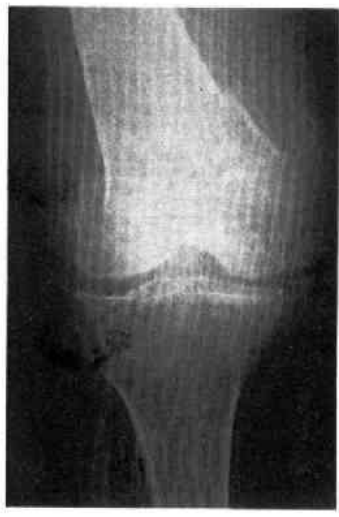

a

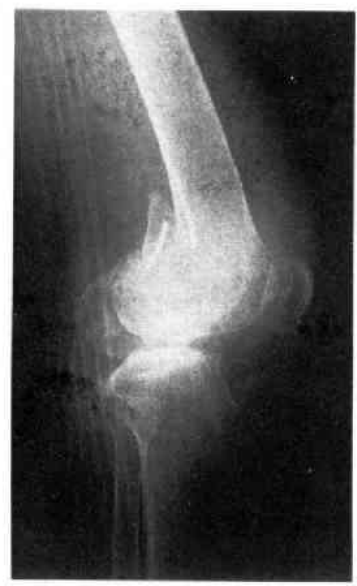

b

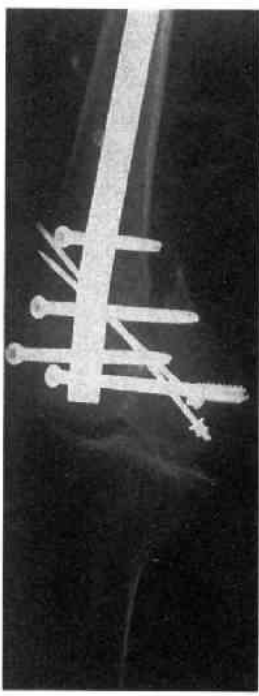

d

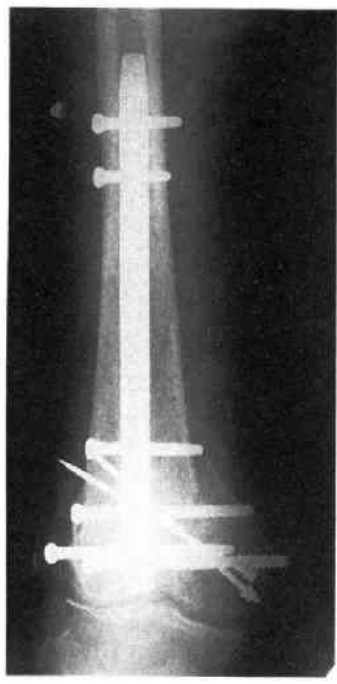

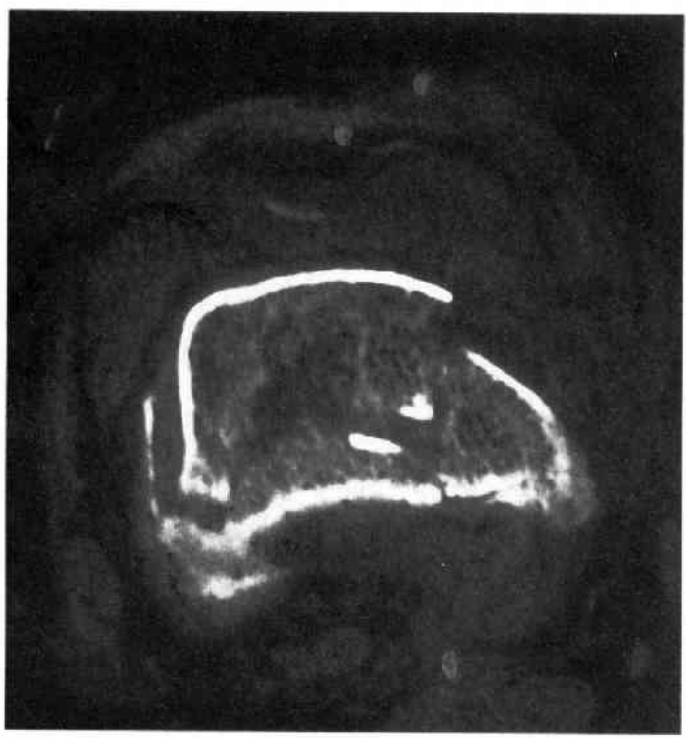

图 1 症例 9 面像所見
a. 術前レントタ゚ン（前後像）
b. 術前レントダン (側面像)
c. 術前 CT
粉砕骨折となっている
d. 術後レントゲン〈斜位像)
e. 術後レントダン（前後像)

顆部後方の骨折の整復が不十分 
良性負血で死亡した 2 例と， 30 年来の脊損により成 綨評価不能の 1 例を除いた，10 例である，受伤時年 㱓は 63〜96 墄で, 平均 78.5 歳。男性 1 例, 女性 9 例 であった．経過観察期間は， 6 力月～ 52 力月（平均 22.8 力月）である。

骨折型の分類は角南の分類 ${ }^{()}$を用い, 成結の評価は Neerの判定基舫")を用いて行った.

$$
\text { 結果 }
$$

骨折型は，骨幹端部に粉砕骨折を伴う血型が 4 例， 内外側に転位を伴うが，顆部骨折を含まないIV A 型 が6例であった（表 1). 固定材は，May-plate 1 例， rush-pin 2 例, DCS 1 例, Intramedullary Supra Condyilar Nail (以下 IMSC) 6 例であった（表 1). 平成 6 年 10 月以降の症例では, 全例 IMSC を使用し ている.

術後成績を見ると（表 2)，症例 $3 ， 5 ， 7$ が Failure

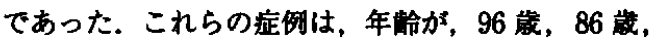
90 歳と高龄で，痴呆が蚛く，また，訓練への意欲も そしく，転院後，网節拘綰をきたし，車いす移動となっ ている症例である，他の症例では，Excellent：4 例， Satisfactory : 3 例と，概ね良好であったが, 症例 1 , 4，10では杖歩行となったため，Function Scoreが やや不良であった，症例 6，9は，可動城が 0 ７0 度 程度と，Motion Scoreがやや不良であった，当院 では，平成 6 年 10 月以降，症例 $5 \sim 10$ で, IMSC を 使用している，今回の対象では，IMSCの症例数，他 の固定材の症例数，ともに少ないので，成績を比較す ることは出来ないが, 今回の IMSC の症例に関して だけ言及すれば，前述の拘縮を起こした症例 2 例以外 は, Excellent 4 例と，比較的良好であった。

\section{考察}

大腿骨顆上骨折は，解剖学的には比較的骨癒合が良 いとされているが，良好な滕阙節機能を得る，という 点に関しては，困䨅を伴うことが多い，治療に難渋す る要因としては，膝関節周囲の筋肉により骨折転位を 来しやすく整復が困難，皮質が薄く鹃腔が広いため十 分な固定性を得にくい，拘縮による膝関節機能障害を 来しやすい，等が，これまでにも言われてきだ516). 高跲者の場合には，さらに，以下のような要因む挙げ られる。
まず，骨粗嶅症の合併により骨強度が脆弱であり， さらにそのため, 粉砕骨折となっている場合, 強固な 内固定が非常に困難となる，症例 9 では，図 1 のよう に粉砕が強く，また，内顆後方を十分に整復すること ができなかった，そのため，支持性の獲得を優先とし， CPM は早期より開始したが, アグレッシブな可動域 訓練は、開始を遅らせた，その結果, 診察時の可動域 は, 0 〜0度と不良であった。

次に，変形性膝関節症の合併により，可動域不良や 疼痛を認める場合がある, 症例 4 は, 手術後, 可動城 が 0 〜 105 度で, 独歩可となっていた。しかし，その 後 OA が進行し, 屈曲が95度と低下し, 起立時等に 㮏関節内㑡に疼痛を認めるようになった。

また，痴呆や全身宪患の合併等により，リハビリを 進めることが困䧿である場合もある．前迈の症例のよ うに，当院退院時にはある程度の可動城が得られてい たのに，痴呆の合併等でリハビリが進まず，拘縮をき たした症例があった.

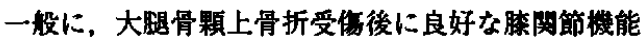
を回復するためには，可能な限り強固な固定を行い， 早期にリハビリテーションを開始することが重要とな る.しかし，高㱓者の場合は，以上述べたように，骨 粗筑症, 変形性膝䦎節症, 全身疾患の合併等が, 強固 な固定, 早期リハビリテーションを困難にする場合が あり，治療成績に大きく関与していると思われた。

大腿骨顆上骨折の治療に関しては, 以前は Neer ら゙をはじめとして，保存的治療の假位性が報告され ていたが, 近年, 早期離床, 早期可動域娪練を行うた め, AO condylar plate, $\mathrm{N}$ 式ブレート, Zickel 釷, IMSC 等，㥞々な固定材が開発され，諸家により ${ }^{12299}$ 良好な成績が報告されている，しかし，高龄者が対象 の場合，問題点の認められた報告も散見され，必ずし む十分とは言い切れない, 我々は現在, IMSC を主に 使用しており，症例数は少ないが良好な成績を得られ ている，今後症例を重ね，その治療成紸に関して，さ らに検討を進めたい。

$$
\text { ま と め }
$$

当院で経験した，大腿学顆上骨折の症例の術後成績 を調查し，その問題点を検討した。

高龄者の大腿骨顆上骨折の場合には, 骨粗唯症, 変 形性膝関節症，全身疾患の合併等が，治療成繢に大き 
く関与しており，比較的安全に，早期荷重，早期可動 域訓練が行える，固定法や固定材の確立が必要と思わ れた.

\section{参考文献}

1）池田 修他：高榆者大腿骨顆上骨折に対する Zickel supracondylar system $の$ 使用経匼。惧整外，28(12)： 1383-1388, 1993.

2）生田拓也, 坂口 满: 大腿骨透位端骨折. 整形- 災害 外科, $39: 349-356,1996$.

3）久我哲也他：高峆者の大腿骨顆上骨折に対する Zickel supracondylar system の使用経験. 整形外科と災害外科, 42(2) : 801-804, 1993.

4) Neer, C.S. et al.: Supracondylar fracture of the adult femur. J. Bone Joint Surg., 49-A : 591-613, 1967.

5) Olerrud, S.: Operative treatment of supracondylar fractures of the femur.J. Bone Joint Surg., 54-A : 1015-1032, 1972.

6）大里鿆治他 : 大腿骨顆上骨折の街後成繶の梌討。整形 外科と災害外科，42(4): 1442-1448, 1993.

7）角南晹文，今井 煡，長野揵治：N式ブレートによる

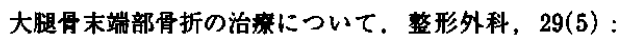
437-443, 1978.

8）高松浩一他：大腿骨下端部骨折の钼血境法. 中部日本 整形外科災害外科学会雑誌，33(3)：1263-1265，1990.

9）田中 䐂他：Ender 法による大腿骨顆上骨折の治㫫経 験。中部日本整形外科災害外科学会雜誌, 33(3)：12651267, 1990. 